\title{
Extent of Livelihood Assets Influence on Livelihood Changes
}

\author{
K. Mahandrakumar*, A. Anitha Pauline and Poovarasan \\ Department of Agricultural Extension and Rural Sociology, AC \& RI, Madurai, India \\ *Corresponding author
}

\section{Keywords \\ Livelihood assets, Livelihood changes, Remittance}

Article Info

Accepted:

28 August 2020

Available Online:

10 September 2020

\section{A B S T R A C T}

Recent trends suggest a large proportion of farming community especially youth in the rural villages is on their way out of agriculture. Rising disenchantment with the agriculture profession pushes them out of their traditional occupation while opportunities in other sectors of the booming economy pull them out of agriculture. This study attempts to identify the factors responsible for this process of withdrawal and assess the influence of livelihood assets on livelihood strategies of farmers in Periyar - Vaigai command area in line with early studies carried out by Bragg and Dalton, 2004; Foltz, 2004; Glauben et al., 2006; Prem B. Bhandari, 2013. Madurai has both single cropped and double cropped area under Periyar- Vaigai irrigation. 100 farmers from single cropped area and another 100 farmers from double cropped area was chosen and thus total of 200 respondents surveyed through structured interview schedule. The analysis of result revealed that 15.5 percent of farm household shifted to non farm income either fully $(7.0 \%)$ or partially $(8.5 \%)$ in the last 5 years and 21.0 percent of farm household shifted to other commercial crops from paddy and Rest $(63.5 \%)$ of farmers have adopted the same livelihood strategy that they had earlier. Leaving from agricultural sector as livelihood strategy is less than 1.5 percent per annum among farming household. In double cropped raised area, there were crop diversification of rice to sugarcane and rice to banana. The irrigated areas were leased out for banana and sugarcane cultivation by the land owners. In the single seasonal cropped area and tenured area there is no shift from paddy. Remittance played an important role in stick on to agricultural occupation. Livelihood Assets had influence on livelihood strategies of the farmers. There are significant differences in possession of livelihood assets by different livelihood strategies adopted by the house holds.

\section{Introduction}

Recent studies suggest a large proportion of farming community in the rural villages is on their way out of agriculture. Bhalla and Hazell (2003) hypothesized that the growth in the secondary and the tertiary sectors has a major contribution in the decline in farmer population. Amrita Sharma (2005) expressed that possession of skill seems to be an important factor in determining outmigration from agriculture. Rising disenchantment with the agriculture profession pushes them out of their traditional occupation while opportunities in other sectors of the booming economy pull them out of agriculture. 
Doddamani (2014) attempted to identify the push and pull factors which influence workers' inter-state migration, on the basis of perceptions of workers. This study attempts to identify the factors responsible for this process of withdrawal and assess the influence of livelihood assets on livelihood strategies of farmers in Periyar - Vaigai command area in line with early studies carried out by Bragg and Dalton, 2004; Foltz, 2004; Glauben et al., 2006; Prem B. Bhandari, 2013.

The main objectives of this study includes to explore the dynamics of livelihood changes and extent of livelihood changes of farm families; In Periyar - Vaigai Command area of Madurai district. To find out the factors responsible for livelihood changes of farm families in Periyar - Vaigai Command area of Madurai district. And also to assess the extent of livelihood assets influence on livelihood changes.

\section{Materials and Methods}

Madurai have both single cropped and double cropped area under Periyar - Vaigai irrigation. 100 farmers from single cropped area and another 100 farmers from double cropped area was chosen and thus total of 200 respondents surveyed through structured interview schedule. The details of sampling are presented in table 1.

\section{Statistical tools used}

Chi- square test was employed to assess the Frequency distributions of respondents who have gone for different livelihood strategies against their assets position.

Mean and Standard Deviation was used to consolidate the differences in asset position of different livelihood changes.
Corretation with probit regression analysis were used to understand the association and degree of influence of assets on livelihood strategies.

Percentage analysis was employed to assess the perceived factors influenced the farmers towards the livelihood strategies.

\section{Extent of livelihood diversification}

A person or household with a diverse livelihood relies on several different economic activities. A 'diverse livelihood' is the opposite of a specialized livelihood based on a single, full-time activity. Diversification is the incorporation of new activities into the economic portfolio. The number of income sources of different households were studied to measure the diversification in this regard and presented.

In the past ( 5 years before) nearly half of the farm household $(54.00 \%)$ had two sources of income followed by one third of them had one and rest of them had three sources of income to run their livelihood. But at present there is slight decrease in single source of income category and slight increase in two and three sources of income category compare to the past.

A detail account of sector wise sources of income revealed that in the single source of income category there is significant number ( 7 percent of crop cultivators and 2 percent of animal husbandry farmers) of farm household left the farming sector. In the double source income categories 4.5 percent in crop cultivators and animal husbandry farm household left the farming sector. As a result there is steady increase in non farm occupation in single $(7.00 \%)$, double $(6.5 \%)$ and three sources (2\%) income category. All together 15.50 percent of farm house hold shifted from farming to non farming 
occupation in the last five years.

Propping the present cultivators revealed that there is shift of crops within the farming sectors . Nearly 21 percent of cultivators shifted from paddy to commercial crops like chewing sugarcane, banana, vegetables and flower crops.

Hence it can be concluded that the farm families in Periyar - Vaigai command area of Madurai have followed three livelihood strategies. They are,

15.5 percent of farm household shifted to non farm income either fully $(7.0 \%)$ or partially $(8.5 \%)$ in the last 5 years.

21.0 percent of farm household shifted to other commercial crops from paddy in the last 5 years and

Rest $(63.5 \%)$ of farmers has adopted the same livelihood strategy that they had 5 years before.

\section{Extent of livelihood assets influence on livelihood changes}

Livelihood changes or strategies based on vulnerability and shock encountered by the households in their life and tackles them by using the livelihood assets available to them. Hence, a detail account of livelihood assets is presented in following tables (Table 2-8).

The table 3 revealed that the big farmers had both farming and to non -farming occupations. It seems that income earned from agriculture is invested in non - farming occupation by these household. Small farmers did not change their livelihood. The traditional outlook and less risk taking ability might have influenced them to be in the same occupation. Mostly the medium size landholders shifted from paddy to commercial cops with in the farming sector.

The tenure land holders stick to agriculture than own land holders. In Vaigai - Periyar command area 31.5 percent of them are tenure land holders who are cultivating paddy on behalf of big land lords or institutions like temple authorities and charitable trusts. In the expansion of city these land are sold for real estate. In that case being cultivators they used to get half of land sale value. This is one of the reasons that these farming household stick to agriculture. In recent years potential irrigated land (i.e. land which had bore well and assured irrigation throughout the year) were leased out for 4 to 6 lakhs / acre for 4 to 5 years. Mostly in the leased land commercial crops are being cultivated.

The data shown in irrigation potentiality and intensity again reiterate that irrigated land are used for commercial crops cultivation. Due to higher cost of labours and non availability of labours farmers preferred to cultivate annual crops like Banana, Sugarcane and Flower crops

The man power assets had influenced the livelihood strategies. Where the size of family is big and more number of persons in a family engaged in agriculture, there is great chance for the household to retain in the agricultural occupations. Similarly when family size is small and less number of persons engaged in agriculture in a family there is great chance for them to be shifted to non- farm occupation. More educated and those who attended more trainings on agriculture have remained in agricultural occupations but shifted to commercial crops.

The non-farm house holds had more assets than other two categories. But the farm assets are more among the commercial crop cultivators than traditional paddy growers. Hence, it can be inferred that possession of 
farm assets influenced the livelihood strategies.

Financial asset favored the farmers to go for the commercial crop cultivators. In other words the commercial crop growers earn not only more farm income but also non-farm income and they borrowed more credit than others.

Higher the social participation then higher the chance of farmers to shift to either commercial crops or non farm income. Obviously, higher the extension agency contact there is great chance for retained in agriculture. Hence, it can be concluded that presence of social asset influence the farmers in different sort of livelihood strategies.

\section{Determinants of farm diversification}

To identify the factors influencing farm diversification, probit model was employed. The results are presented in Table 4 and 5.

The variables farm size, education, farm own labour, household asset, farm asset, farm income, credit availed and extension contact had positive association with extent of livelihood diversification at one percent level of significant. Irrigation potentiality had positive association and family size had negative association with extent of livelihood changes at five percent level of significant.

To identify the factors influencing farm diversification, probit model was employed.

The results revealed that irrigation intensity had shown positive and significant contribution at one percent level of probability whereas farm income had positive and significant contribution at five per cent level of probability. Extension contact had shown negative and significant contribution at one per cent probability level. However,
Household farm labour and farm asset were found to have positive and non-significant contribution to farm diversification.

$\mathrm{D}_{\mathrm{i}}=-2.007^{* *}+2.038^{* *} \mathrm{~F}_{1}+0.358^{\mathrm{NS}} \mathrm{F}_{2}+$ $0.003{ }^{\mathrm{NS}} \mathrm{F}_{3}-0.742^{* *} \mathrm{~F}_{4}+0.064^{*} \mathrm{~F}_{5}$

Factors responsible for livelihood changes of farm families

There were three livelihood strategies being followed by the household of farm families in Periyar -Vaigai command area. They are 1.Continuing the same occupation 2.Change with in the occupation and 3.Leaving the occupation. To asses the qualitative factors, the respondents were asked to express the reasons for such strategies which is presented in table 6 .

More than half of the respondents who retained in farming sector perceived that fear of risk to enter in other occupations (56.69), availability of food grains for their consumption (54.33), being aged wish to be in local village (51.18) and availability of sufficient family labourers (50.39). Nearly forty percent of present day cultivators expressed sufficient income, engaged in paddy cultivation in only one season and remittance in agriculture from other family members are the major reasons. One third of the farm holders stated that they are in farming sector because of remittance by other family members .Nearly one fourth of farmers felt that possession of land holding give them pride and the subsidies availed for agriculture made them to be retained in farming sector and they expect farming sector will have near bright future.

More than ninety percent of the respondents who shifted to commercial crops with in the farming sector perceived that they could earn better income than paddy and they could shift to annual crops due to possession of perennial 
irrigation sources like bore well. Nearly two third of the present day commercial crop cultivators stated that Subsidies like drip fertigation and mulching available for promotion of commercial crops and Fear of risk to enter in non - farm occupations as reasons. Immediate payment for the farm produce like vegetables and flowers and Scarcity of labours that limit them in continuous engagement for seasonal crops was quoted by half of the commercial crop cultivators. Nearly one third of changed crop growers stated Unavailability of male to manage the farming, Remittance in agriculture from other family members, Scope of betterment in near future and forty percent stated growing of commercial crops help them to save time.

From table 8 it is revealed that more than ninety percent of the respondents who shifted toward non - farming sector stated high cost of farm input and less income from farming were reasons for livelihood changes. Two third of them felt Non availability of labours in peak or crucial stage, Increased Labour cost after Implementation on MGNREGA and scarcity of water for crop cultivation are the reasons for shifted toward non - farming sector. Around sixty present of household who recently shifted to non - farming sector stated the push factors like frequent incidence of pest and diseases, Frequent dry spell, High Hiring charges of farm machineries and pull factors like Fixed hour of work with guarantee payment of salary/wages in nonfarming sector, fixed hour of work, No need for invest money as in farming as the reasons. Situational factors like availability of communication and transport facilities in villages and rise of land value favored fifty percent of them to go for non - farming sector. Some of the psychological perception of farmers like Stigma of feeling agriculture as inferior and drudgery and free from the clutch of land lords and dominant caste also quoted for shift by significant number of farm household.

Table.1 The details of sampling

\begin{tabular}{|c|c|c|c|}
\hline Sample area & Block & Villages & $\begin{array}{l}\text { No. of. } \\
\text { Respondents }\end{array}$ \\
\hline \multirow[t]{2}{*}{$\begin{array}{l}\text { Doubled cropped } \\
\text { area }(n=100)\end{array}$} & Vaddipatti & $\begin{array}{l}\text { 1.Mettunerathan } \\
\text { 2.Nachikulam }\end{array}$ & $\begin{array}{l}25 \\
25\end{array}$ \\
\hline & Alanganallur & $\begin{array}{l}\text { 1. Kondyampatti } \\
\text { 2.Ambalathadi }\end{array}$ & $\begin{array}{l}25 \\
25\end{array}$ \\
\hline \multirow[t]{2}{*}{$\begin{array}{l}\text { Single cropped area } \\
(n=100)\end{array}$} & Mellur & $\begin{array}{l}\text { 1.Thamaraipatti } \\
\text { 2.Navinipatti }\end{array}$ & $\begin{array}{l}25 \\
25\end{array}$ \\
\hline & Thiruparakundram & $\begin{array}{l}\text { 1.Villacherry } \\
\text { 2.Nilayur }\end{array}$ & $\begin{array}{l}25 \\
25\end{array}$ \\
\hline
\end{tabular}


Table.2 Measurement of Farm Household Livelihood Assets

\begin{tabular}{|c|c|}
\hline Type of Assets & Measurement procedure \\
\hline \multicolumn{2}{|l|}{ Natural assets } \\
\hline Farm size (ha.) & $\begin{array}{l}\text { Refers to cultivable area possessed by an individual house hold. } \\
\text { it was measured in terms of hectare. }\end{array}$ \\
\hline Ownership pattern. & $\begin{array}{l}\text { The three types of possession of land holding such as owned, } \\
\text { leased and tenured was assessed. }\end{array}$ \\
\hline Irrigation intensity(\%) & $\begin{array}{l}\text { Measured through number of crops raised in cultivable area } \\
\text { through irrigation in a year. }\end{array}$ \\
\hline $\begin{array}{l}\text { Irrigation potentiality } \\
\text { (in no. of season) }\end{array}$ & $\begin{array}{l}\text { Measured through number of crops can be raised in cultivable } \\
\text { area through different sources of irrigation (such as cannel, tank } \\
\text { and well ) in a year }\end{array}$ \\
\hline \multicolumn{2}{|l|}{ Manpower assets } \\
\hline Family size (no.) & $\begin{array}{l}\text { Measured in term of number of adult (above age 18) in a house } \\
\text { hold }\end{array}$ \\
\hline $\begin{array}{ll}\text { Household } & \text { Head } \\
\text { education (Std) }\end{array}$ & $\begin{array}{l}\text { Measured in term of number of years the head of the household } \\
\text { undergone the formal education. }\end{array}$ \\
\hline $\begin{array}{l}\text { Availabity of Family } \\
\text { Labours (no.) }\end{array}$ & $\begin{array}{l}\text { Number of household members involved in agricultural } \\
\text { operations. }\end{array}$ \\
\hline Training under gone (no.) & $\begin{array}{l}\text { Number of trainings related to agriculture undergone by a family } \\
\text { member in the last two years. }\end{array}$ \\
\hline \multicolumn{2}{|l|}{ Material assets } \\
\hline Household assets (lakhs) & $\begin{array}{l}\text { Measured in terms of money value. it includes plot, house, } \\
\text { transport vehicles and other household utensils. }\end{array}$ \\
\hline Farm assets (lakhs) & $\begin{array}{l}\text { Measured in terms of money value. it includes land, farm } \\
\text { equipments and machineries. }\end{array}$ \\
\hline \multicolumn{2}{|l|}{ Financial assets } \\
\hline $\begin{array}{l}\begin{array}{l}\text { Annual } \\
\text { (lakhs) }\end{array} \\
\text { Farm income }\end{array}$ & $\begin{array}{l}\text { Income earned through selling of produce and other economic } \\
\text { activities in a year }\end{array}$ \\
\hline $\begin{array}{l}\text { Annual } \\
\text { income (lakhs) }\end{array}$ & Income earned through other than farming in a year \\
\hline Credit availed (lakhs) & Amount of credit availed for economic and social activities \\
\hline \multicolumn{2}{|l|}{ Social assets } \\
\hline Social participation (no.) & $\begin{array}{l}\text { It was measured in terms of head of household being a member } \\
\text { or office bearer in organizations . }\end{array}$ \\
\hline Extension contact (no.) & $\begin{array}{l}\text { It was measured in terms of head of household had a number of } \\
\text { contact with agricultural extension agencies for the last two } \\
\text { years. }\end{array}$ \\
\hline
\end{tabular}


Table.3 Comparison of Five Livelihood Assets of Farm Households had Different Livelihood Strategies

\begin{tabular}{|c|c|c|c|c|c|c|c|c|}
\hline \multirow[t]{2}{*}{ Type of Assets } & \multicolumn{2}{|c|}{$\begin{array}{l}\text { Total } \\
\text { Samples } \\
(n=200)\end{array}$} & \multicolumn{2}{|c|}{$\begin{array}{l}\text { Shifted to Non- } \\
\text { Farming Sector } \\
(\mathrm{n}=31)\end{array}$} & \multicolumn{2}{|c|}{$\begin{array}{l}\text { Shifted with in } \\
\text { the Farming } \\
\text { Sector } \\
(n=42)\end{array}$} & \multicolumn{2}{|c|}{$\begin{array}{l}\text { Stayed in the } \\
\text { Same sector } \\
(n=127)\end{array}$} \\
\hline & Mean & S.D & Mean & S.D & Mean & S.D & Mean & S.D \\
\hline \multicolumn{9}{|l|}{ Nature assets } \\
\hline Farm size (ha.) & 1.70 & 0.82 & 2.26 & 0.86 & 1.760 & 0.76 & 1.54 & 0.77 \\
\hline $\begin{array}{l}\text { Ownership } \\
\text { pattern }\end{array}$ & 1.74 & 0.90 & 1.56 & 0.72 & 1.64 & 0.75 & 1.83 & 0.96 \\
\hline $\begin{array}{l}\text { Irrigation } \\
\text { intensity( } \%)\end{array}$ & 127.00 & 28.00 & 116.00 & 26.00 & 149.00 & 25.00 & 122.00 & 26.00 \\
\hline $\begin{array}{l}\text { Irrigation } \\
\text { potentiality } \\
\text { (in no. of season) }\end{array}$ & 1.60 & 0.72 & 1.42 & 0.67 & 2.28 & 0.72 & 1.40 & 0.57 \\
\hline \multicolumn{9}{|l|}{ Manpower assets } \\
\hline Family size (no.) & 5.84 & 1.64 & 5.11 & 1.75 & 6.07 & 1.48 & 5.94 & 1.63 \\
\hline $\begin{array}{l}\text { Household Head } \\
\text { education(std) }\end{array}$ & 6.74 & 3.53 & 9.10 & 3.77 & 9.43 & 3.37 & 5.25 & 2.54 \\
\hline $\begin{array}{l}\text { Availabity of } \\
\text { Farm (own) } \\
\text { Labour (no.) }\end{array}$ & 2.12 & 0.87 & 1.45 & 0.77 & 2.14 & 0.84 & 2.28 & .082 \\
\hline $\begin{array}{l}\text { Training under } \\
\text { gone (no.) }\end{array}$ & 1.66 & 0.77 & 1.29 & 0.59 & 2.26 & 0.73 & 1.54 & 0.71 \\
\hline \multicolumn{9}{|l|}{ Material assets } \\
\hline $\begin{array}{l}\text { Household assets } \\
\text { (lakhs) }\end{array}$ & 37.74 & 1.44 & 45.87 & 1.18 & 45.04 & 1.1 & 33.33 & 1.33 \\
\hline $\begin{array}{l}\text { Farm assets } \\
\text { (lakhs) }\end{array}$ & 10.58 & 5.66 & 11.45 & 5.27 & 15.05 & 3.92 & 8.87 & 5.39 \\
\hline \multicolumn{9}{|l|}{ Financial assets } \\
\hline $\begin{array}{l}\text { Annual Farm } \\
\text { income (lakhs) }\end{array}$ & 3.72 & 2.17 & 3.56 & 2.15 & 5.83 & 1.83 & 3.07 & 1.81 \\
\hline $\begin{array}{l}\text { Annual Non- } \\
\text { farm income } \\
\text { (lakhs) }\end{array}$ & 1.93 & 0.81 & 2.0 & 0.86 & 2.14 & 0.84 & 1.83 & 0.77 \\
\hline $\begin{array}{l}\text { Credit availed } \\
\text { (lakhs) }\end{array}$ & 1.64 & 0.65 & 1.62 & 0.65 & 2.11 & 0.58 & 1.50 & 0.61 \\
\hline \multicolumn{9}{|l|}{ Social assets } \\
\hline $\begin{array}{l}\text { Social } \\
\text { participation (no.) }\end{array}$ & 5.60 & 1.84 & 6.05 & 1.80 & 5.79 & 1.89 & 5.43 & 1.82 \\
\hline $\begin{array}{l}\text { Extension contact } \\
\text { (no.) }\end{array}$ & 4.08 & 1.80 & 2.73 & 1.15 & $4 . .32$ & 1.8 & 4.33 & 1.77 \\
\hline
\end{tabular}




\begin{tabular}{|c|c|c|c|c|c|}
\hline \multicolumn{2}{|c|}{$\begin{array}{l}\text { Table.4 Association of livelihood assets } \\
\text { with Extent of Livelihood Changes }\end{array}$} & \multirow{2}{*}{\multicolumn{4}{|c|}{$\begin{array}{l}\text { Table.5 Determinants of farm diversification } \\
\qquad(\mathbf{n = 2 0 0 )}\end{array}$}} \\
\hline livelihood assets & "r" value & & & & \\
\hline Farm size & $0.304 * *$ & \multirow[t]{2}{*}{ Variables } & \multirow[t]{2}{*}{ Estimate } & \multirow{2}{*}{$\begin{array}{l}\text { Standard } \\
\text { error }\end{array}$} & \multirow[t]{2}{*}{ Z-value } \\
\hline Ownership & -0.123 & & & & \\
\hline Irrigation intensity & 0.060 & \multirow[t]{2}{*}{ Intercept } & \multirow[t]{2}{*}{-2.007} & \multirow[t]{2}{*}{0.593} & \multirow{2}{*}{$3.382 * *$} \\
\hline Irrigation & $0.169 *$ & & & & \\
\hline potentiality & & \multirow{3}{*}{$\begin{array}{l}\text { Irrigation } \\
\text { intensity } \\
\text { (F1) }\end{array}$} & \multirow[t]{3}{*}{2.038} & \multirow[t]{3}{*}{0.748} & \multirow[t]{3}{*}{$2.725^{* *}$} \\
\hline Family size & $-0.144^{*}$ & & & & \\
\hline Education & $0.502 * *$ & & & & \\
\hline Farm own labour & $0.313 * *$ & \multirow{4}{*}{$\begin{array}{l}\text { Household } \\
\text { farm } \\
\text { labour(F2) }\end{array}$} & \multirow{4}{*}{0.358} & \multirow{4}{*}{0.269} & \multirow[t]{4}{*}{1.329} \\
\hline Training & 0.025 & & & & \\
\hline Household asset & $0.376 * *$ & & & & \\
\hline Farm asset & $0.287 * *$ & & & & \\
\hline Farm income & $0.243 * *$ & \multirow{2}{*}{$\begin{array}{l}\text { Farm } \\
\operatorname{asset}(\mathbf{F 3})\end{array}$} & \multirow{2}{*}{0.003} & \multirow{2}{*}{0.011} & \multirow{2}{*}{0.252} \\
\hline Non- farm income & 0.114 & & & & \\
\hline Credit availed & $0.186^{* *}$ & \multirow{2}{*}{$\begin{array}{l}\text { Extension } \\
\operatorname{contact}(\mathbf{F} 4)\end{array}$} & \multirow[t]{2}{*}{-0.742} & \multirow[t]{2}{*}{0.104} & \multirow{2}{*}{$7.161 * *$} \\
\hline Social participation & 0.129 & & & & \\
\hline \multirow[t]{2}{*}{ Extension contact } & $0.275 * *$ & $\begin{array}{l}\text { Farm } \\
\text { income(F5) }\end{array}$ & 0.064 & 0.032 & $2.000 *$ \\
\hline & & \multicolumn{4}{|c|}{$\begin{array}{l}\text { Prob }>\text { chi square }=12.401^{\mathrm{NS}} \\
\mathrm{R}^{2}=0.568 \\
* * \text {-Significant at one percent level } \\
* \text {-Significant at five percent level } \\
\mathrm{R}^{2=} 0.568\end{array}$} \\
\hline
\end{tabular}


Table.6 Factors perceived by the respondents to be retained in farming sector

\begin{tabular}{|l|l|c|c|}
\hline SI.No. & Factors perceived by the respondents & No. & \% \\
\hline 1. & Fear of risk to enter in other occupations & 72 & 56.69 \\
\hline 2. & Availability of food grains for their consumption & 69 & 54.33 \\
\hline 3. & Being aged wish to be in local village. & 65 & 51.18 \\
\hline 4. & Availability of sufficient familylabourers & 64 & 50.39 \\
\hline 5. & Sufficient income & 57 & 44.88 \\
\hline 6. & To be engaged in only one season. & 54 & 42.52 \\
\hline 7. & Remittance in agriculture from other family & 50 & 39.37 \\
\hline 8. & members & 43 & 33.86 \\
\hline 9. & Fear of loosing tenure status & 34 & 26.77 \\
\hline 10. & Subsidies available for agriculture & 34 & 26.77 \\
\hline 11. & Scope of betterment in future & 32 & 25.20 \\
\hline
\end{tabular}

Table.7 Factors Perceived by the Respondents to Shift towards Commercial Crops ( $\mathrm{n}=42$ )

\begin{tabular}{|r|r|c|c|}
\hline Sl.No & Factors perceived by the respondents & No. & \% \\
\hline $\mathbf{1 .}$ & More profit than paddy & 40 & 97.56 \\
\hline $\mathbf{2 .}$ & Availability of water throughout the year & 38 & 92.68 \\
\hline $\mathbf{3 .}$ & Subsidies available for promotion of commercial crops & 28 & 68.29 \\
\hline $\mathbf{4 .}$ & Fear of risk to enter in non - farm occupations & 26 & 63.41 \\
\hline $\mathbf{5 .}$ & Immediate payment for the farm produce & 22 & 53.66 \\
\hline $\mathbf{6 .}$ & Scarcity of labours to go for seasonal crop & 21 & 51.22 \\
\hline $\mathbf{7 .}$ & No need to engage in full time as that of paddy & 18 & 43.90 \\
\hline $\mathbf{8 .}$ & Unavailability of male to manage the farming & 15 & 36.59 \\
\hline $\mathbf{9 .}$ & Remittance in agriculture from other family members & 14 & 34.15 \\
\hline $\mathbf{1 0}$ & Scope of betterment in near future & 13 & 31.71 \\
\hline
\end{tabular}


Table.8 Factors perceived by the respondents to shift towards non-farming income $(\mathrm{n}=31)$

\begin{tabular}{|c|c|c|c|}
\hline Sl.no & Factors perceived by the respondents & No. & $\%$ \\
\hline 1. & High cost of farm input & 30 & 96.77 \\
\hline 2. & less income from farming & 29 & 93.55 \\
\hline 3. & Non availability of labours in peak or crucial stage & 21 & 67.74 \\
\hline 4. & Increased Labour cost after Implementation on MGNREGA & 21 & 67.74 \\
\hline 5. & Non -availability of water throughout the season & 20 & 64.52 \\
\hline 6. & Fixed hour of work with guarantee payment of salary/wages & 19 & 61.29 \\
\hline 7. & Frequent incidence of pest and diseases & 19 & 61.29 \\
\hline 8. & No need to engage full time as that of farming & 19 & 61.29 \\
\hline 9. & Frequent dry spell & 18 & 58.06 \\
\hline 10 & Hiring charges of farm machineries are high. & 18 & 58.06 \\
\hline 11. & No need to invest money as in farming & 17 & 54.84 \\
\hline 12. & $\begin{array}{l}\text { Availability of communication and transport facilities in } \\
\text { village }\end{array}$ & 16 & 51.61 \\
\hline 13. & Rise of Land value & 16 & 51.61 \\
\hline 14. & Stigma of feeling agriculture as inferior and drudgery & 12 & 38.71 \\
\hline 15. & Unavailability of family members to manage the farming & 11 & 35.48 \\
\hline 16. & Free from the clutch of land lords and dominant caste & 10 & 32.26 \\
\hline 17. & Family dispute on ownership on land. & 8 & 25.81 \\
\hline
\end{tabular}

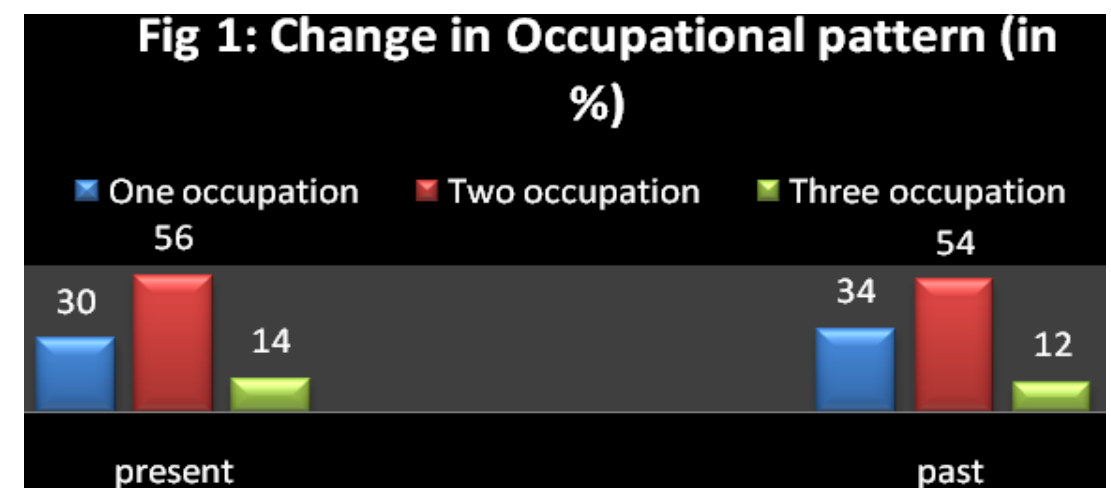



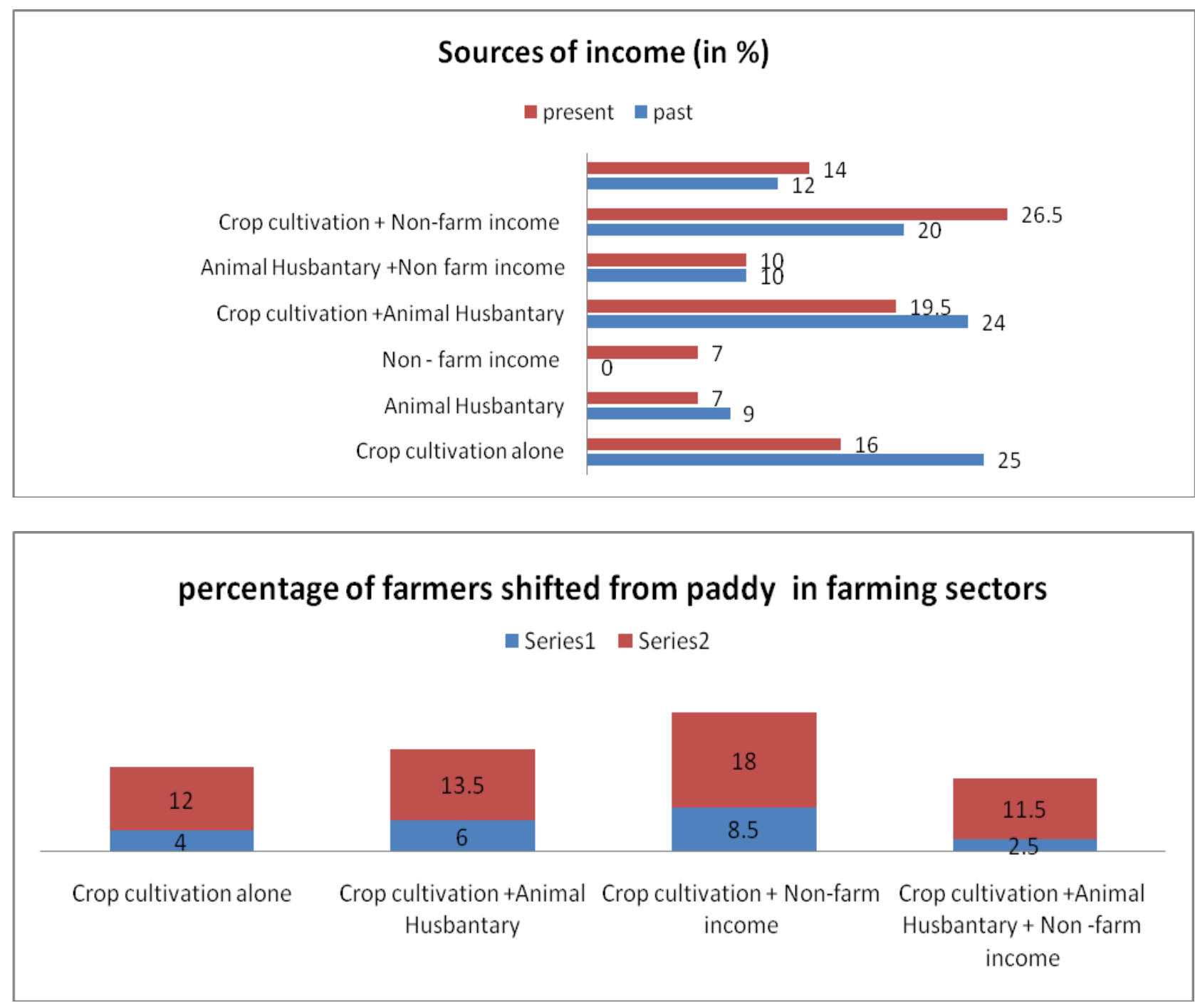

\section{Salient findings}

In Periyar -Vaigai commend area, 15.5 percent of farm household shifted to non farm income either fully $(7.0 \%)$ or partially $(8.5 \%)$ in the last 5 years. Another 21.0 percent of farm household shifted to other commercial crops from paddy and rest $(63.5 \%)$ of farmers have adopted the same livelihood strategy that they had earlier. Leaving from agricultural sector as livelihood strategy is less than 1.5 percent per annum among farming household, livestock farm holders did not change their livelihood strategies.

In double cropped raised area there were crop diversification of rice to sugarcane and rice to banana. The irrigated areas were leased out for banana and sugarcane cultivation by the land owners.

In the single seasonal cropped area and tenured area there is no shift from paddy. Remittance played Important role in stick on to agricultural occupation. Livelihood Assets had influenced on livelihood strategies of the farmers. There is significant differences in possession of livelihood assets by different livelihood strategies adopted house holds. In fact, the natural asset, social asset and economic assets are the determinant for 
farmers to be retained in agriculture.

\section{Implication of the study}

Since subsidies played a major role for continuance in agriculture it must be continued.

Livestock sector must be encouraged as a entrepreneurship activity among farm holders.

The encroachment in system tank must be averted for continuance of agriculture.

Dispute on Leased land between parties are increasing. Suitable regulations must be enforced.

There is shift towards alternative commercial crops. Extension officials in state horticultural department may be enhanced. Suitable marketing facilities on these crops may be developed.

\section{References}

Amrita Sharma.2005. The "Tipping Point" in Indian Agriculture: Understanding the Withdrawal of the Indian, Rural Youth. Asian Journal of Agriculture and Development, Vol. 6, No. 1. PP. 83-96.

Bhalla, G.S. and P. Hazell. 2003. "Rural Employment and Poverty: Strategies to Eliminate Rural Poverty within a Generation", Economic and Political Weekly 38 (33).

Bragg, L.A., Dalton, T.J., 2004. Factors affecting the decision to exit dairy farming: a two-stage regression analysis. Journal of Dairy Science 87,PP 3092- 3098

Doddamani.2014. A Study on Migration of Agriculture Labourers from Hyderabad Karnataka Area to Maharashtra, IOSR Journal Of Humanities And Social Science (IOSR-JHSS) Volume 19, Issue 5, Ver. III (May. 2014), PP 68-71 e-ISSN: 2279-0837, p-ISSN: 2279-0845.

Foltz, J.D., 2004. Entry, exit, and farm size: assessing an experiment in dairy price policy. American Journal of Agricultural Economics.86, 594 -604.

Glauben, T., Tietje, H., Weiss, C., 2006. Agriculture on the move: exploring regional differences in farm exit rates. Jahrbuch fur Regional wissenschaft 26, PP.103 -118.

Prem B. Bhandari, 2013 Rural livelihood change? Household capital, community resources and livelihood transition. Journal of Rural Studies, 32. PP.126 -136

\section{How to cite this article:}

Mahandrakumar, K., A. Anitha Pauline and Poovarasan. 2020. Extent of Livelihood Assets Influence on Livelihood Changes. Int.J.Curr.Microbiol.App.Sci. 9(09): 3716-3727. doi: https://doi.org/10.20546/ijcmas.2020.908.429 